\title{
Failure of exogenous IGF-I to restore normal growth in rats submitted to dietary zinc deprivation
}

\author{
N X Ninh, D Maiter, J Verniers, P Lause, J M Ketelslegers and \\ J P Thissen
}

Diabetes and Nutrition Unit, School of Medicine, Catholic University of Louvain, B-1200 Brussels, Belgium

(Requests for offprints should be addressed to J P Thissen, Diabetes and Nutrition Unit, UCL/DIAB 5474, Avenue Hippocrate 54, B-1200 Brussels, Belgium)

\begin{abstract}
Dietary zinc deficiency in rats causes growth retardation associated with decreased circulating IGF-I concentrations. To investigate the potential role of low IGF-I in this condition, we attempted to reverse the growth failure by administration of exogenous IGF-I. Rats were fed for 4 weeks a zinc-deficient diet (ZD, Zn 0 ppm) or were pair-fed a zinc-normal diet (PF, Zn 75 ppm). We compared the anabolic action of recombinant human (rh) IGF-I infused at the dose of $120 \mu \mathrm{g} /$ day for the last experimental week in ZD, PF and freely fed control (CTRL) rats. Zinc deficiency caused growth stunting (weight gain $47 \%$ of PF; $P<0 \cdot 001$ ), decreased circulating IGF-I $(52 \%$ of PF; $P<0 \cdot 01)$ and liver IGF-I mRNA $(67 \%$ of PF; $P<0 \cdot 01)$. Serum insulin-like growth factor-binding protein-3 (IGFBP-3) assessed by ligand blot was also
\end{abstract}

reduced in $\mathrm{ZD}$ rats $(65 \%$ of $\mathrm{PF} ; P<0 \cdot 01)$. While exogenous IGF-I increased body weight in CTRL (+12 g; $P<0 \cdot 01)$ and $\mathrm{PF}(+7 \mathrm{~g}$; not significant) animals, growth was not stimulated in $\mathrm{ZD}$ rats $(-1.5 \mathrm{~g})$ in comparison with the corresponding untreated groups. However, circulating IGF-I and IGFBP-3 levels were restored by IGF-I infusion to levels similar to those in untreated CTRL rats. In conclusion, restoration of normal circulating levels of IGF-I and IGFBP-3 by rhIGF-I infusion fails to reverse the growth retardation induced by zinc deficiency. These results suggest that growth retardation related to zinc deficiency is not only caused by low serum IGF-I concentrations, but also by inhibition of the anabolic actions of IGF-I.

Journal of Endocrinology (1998) 159, 211-217

\section{Introduction}

Insulin-like growth factor-I (IGF-I) mediates most of the post-natal growth-promoting actions of growth hormone (GH). Besides GH (Gronowski \& Rotwein 1995), insulin (Maes et al. 1983) and protein intake (Thissen et al. 1994), micronutrients like zinc have also been shown to control IGF-I synthesis and its release into the circulation (Ninh et al. 1995). Indeed, in rats, as in humans, dietary zinc deprivation is associated with low serum IGF-I concentrations. Previous experiments of our group have shown that the decline in IGF-I caused by zinc deprivation results from a state of GH resistance (Ninh et al. 1997).

Reduced circulating IGF-I levels have been proposed as a potential mechanism for the growth retardation induced by zinc deficiency (Cossack 1984, Oner et al. 1984). This hypothesis is supported by several observations showing that zinc deficiency rapidly induces several changes in the somatotrope axis leading to decreased IGF-I (Bolze et al. 1987, Dorup et al. 1991). However, given its role in the regulation of several enzymes involved in cell proliferation (e.g. thymidine kinase and RNA polymerase), zinc might also control growth independently of changes in circulating IGF-I.
The goal of this study was therefore to investigate whether restoring circulating IGF-I concentrations to normal, despite the persistence of zinc deficiency, would allow resumption of normal growth rates. Therefore, zinc-deprived rats were continuously infused with exogenous IGF-I in an attempt to reverse the decline of IGF-I and the growth retardation.

\section{Materials and Methods}

\section{Experimental design}

Three-week-old female Wistar rats $(n=36)$ were housed in individual metabolic cages with stainless steel frames. The animals were kept under controlled conditions of temperature $\left(22 \pm 2{ }^{\circ} \mathrm{C}\right)$, humidity $(53 \%)$ and lighting $(12 \mathrm{~h}$ light: $12 \mathrm{~h}$ darkness). After adaptation to metabolic cages and to a powdered zinc-normal diet ( $\mathrm{Zn} 75 \mathrm{ppm})$ for 7 days, the rats were randomly distributed into three dietary groups (12 rats/group): (1) rats given a freely available zinc-normal diet (CTRL group); (2) rats given a freely available zinc-deficient diet (Zn 0 ppm) (ZD); and (3) rats serving as pair-fed animals and receiving a zinc-normal 
diet in the same absolute amount as that consumed the day before by the ZD group (PF). The experimental period lasted 4 weeks, and in each dietary group, six rats received a continuous infusion of $120 \mu \mathrm{g}$ IGF-I/day by means of an s.c. osmotic minipump during the last week of the experimental period (CTRL+IGF-I, PF+IGF-I, ZD+IGF-I) while the six other rats received saline (CTRL, PF, ZD). The semi-synthetic zinc-normal and zinc-free fodders were obtained through the UAR company (Villemoisson-sur-Orge, France). The ZD diet had an energy content of $1.33 \mathrm{MJ}(318 \mathrm{kcal}) / 100 \mathrm{~g}$ and contained (per $100 \mathrm{~g}$ ) $20 \mathrm{~g}$ protein, $6 \mathrm{~g}$ fat, $60 \mathrm{~g}$ dextrose, $6 \mathrm{~g}$ cellulose, $1 \mathrm{~g}$ vitamin mixture and $7 \mathrm{~g}$ inorganic salts without zinc. This diet was supplemented with $\mathrm{ZnSO}_{4} \cdot \mathrm{H}_{2} \mathrm{O}(206 \mathrm{mg} / \mathrm{kg}$ powdered diet $)$ to obtain a zinc-normal diet (Zn 75 ppm). The animals had free access to deionized water throughout the experimental period.

Recombinant human (rh) IGF-I $(5 \mathrm{mg} / \mathrm{ml})$ used for treatment was kindly provided by Pharmacia \& Upjohn (Stockholm, Sweden). The osmotic minipumps (Model 2001, Alza Corporation, Palo Alto, CA, USA) were implanted on the back of the rats under light ether anesthesia.

Body weight and food consumption were recorded each morning. After the 4-week experimental period, the animals were killed by decapitation between 1100 and $1200 \mathrm{~h}$. Blood was collected from trunk vessels into glass tubes, allowed to clot at $4{ }^{\circ} \mathrm{C}$ for at least $1 \mathrm{~h}$ and centrifuged at $1000 \mathrm{~g}$ for $15 \mathrm{~min}$ at $4{ }^{\circ} \mathrm{C}$. The sera were stored at $-20{ }^{\circ} \mathrm{C}$ until assayed for hormones, binding proteins and glycemia. Livers were flash-frozen in liquid nitrogen and stored at $-70{ }^{\circ} \mathrm{C}$ until assayed for IGF-I and insulin-like growth factor-binding protein-3 (IGFBP-3) mRNAs. The protocol of this study was approved by the Institutional Animal Care and Use Committee of the University of Louvain at Brussels.

\section{RIAs}

Serum IGF-I concentrations were measured by RIA on serum samples after removal of the binding proteins by chromatography on Sep-Pak C18 cartridges (Waters, Milford, MA, USA) (Davenport et al. 1988). Rat GH and insulin were measured by RIAs, using previously described methods (Maiter et al. 1989).

\section{Glycemia determination}

Serum glucose was measured by the glucose oxidase method (Beckman Gluco-analyzer 2, Palo Alto, CA, USA).

\section{Measurement of serum IGFBPs}

Serum IGFBPs levels were assessed by ligand blotting (Clemmons et al. 1989). Serum samples were size- fractionated by SDS-PAGE in a Laemmli buffer system under nonreducing conditions, electroblotted onto nylon filters, then probed with $10^{6}$ c.p.m. $/ \mathrm{ml}$ (total $\mathrm{vol}=4 \mathrm{ml}$ ) ${ }^{125}$ I-rhIGF-II kindly provided by Eli Lilly (Indianapolis, IN, USA) and visualized by autoradiography at $-70{ }^{\circ} \mathrm{C}$. The autoradiograms were scanned using an Ultroscan XL laser densitometry (LKB-Bromma, Bromma, Sweden) and the results are expressed as arbitrary scanning densitometric units. For each sample, density signals were determined for the 45-39 $\mathrm{kDa}$ (various glycosylated species of IGFBP-3), the 34-29 kDa (IGFBP-1 and -2 essentially), and the $24 \mathrm{kDa}$ (most likely IGFBP-4) bands. The 34$29 \mathrm{kDa}$ bands were analyzed together because they could not be reliably separated for quantification by scanning densitometry. The abundance of IGFBPs in a pool of sera from normal rats served as control. The size of radioactive protein bands was estimated by comparison to standards from Bethesda Research Laboratories (Gaitherburg, MD, USA).

\section{Northern blot hybridization}

Total RNA was isolated from individual liver tissues (four rats per group) by the guanidinium thiocyanate/ cesium chloride method (Chirgwin et al. 1977). Total RNA $(20 \mu \mathrm{g} / \mathrm{lane})$ samples were size separated on a formaldehyde/agarose gel and transferred to Hybond membranes (Amersham, Bucks, UK) by overnight vacuum blotting (Vacugene, Pharmacia, Uppsala, Sweden). After UV cross-linking, the membranes were sequentially hybridized to ${ }^{32} \mathrm{P}-$ labeled cRNA probes specific for rat IGF-I and IGFBP-3 mRNAs, using previously reported methods (Thissen et al. 1991a).

The IGF-I cRNA probe was transcribed from the 194 bp AvaII-Hinfl rat IGF-I exon 4 cDNA fragment inserted into the plasmid vector Bluescript, using T7 RNA polymerase (Life Technologies, Merelbeke, Belgium). The IGFBP-3 riboprobe was transcribed from the 452 bp HindIII-BamHI rat IGFBP-3 cDNA fragment inserted into the plasmid vector Bluescript, using T3 RNA polymerase. Specific activity of these probes was $10^{9}$ c.p.m./ $\mu$ g. Hybridization with a human ${ }^{32} \mathrm{P}-$ labeled rRNA $18 \mathrm{~S}$ antisense (Oncogenene Science, Inc., NY, USA) was subsequently performed to estimate the variation in RNA loading. Blots were exposed to X-ray films (X-Omat AR, Kodak, NY, USA) for 12 to $72 \mathrm{~h}$ at $-70{ }^{\circ} \mathrm{C}$. The amount of hybridized mRNA was quantified by scanning of autoradiograms using an Ultroscan XL laser densitometry scanner (LKB-Bromma).

\section{Statistical analysis}

Data were analyzed by one-way ANOVA followed by Student-Newman-Keuls test to compare multiple means. In the presence of significant heterogeneity of variance 
Table 1 Effect of a 4-week zinc deficiency on body weight gain and food intake. Data are expressed as means \pm S.E.M. $(n=6 /$ group $)$

\begin{tabular}{|c|c|c|c|}
\hline & CTRL & PF & ZD \\
\hline Body weight gain (g) & $56 \cdot 4 \pm 2 \cdot 3$ & $38 \cdot 3 \pm 2 \cdot 5^{+++}$ & $17 \cdot 8 \pm 2 \cdot 9^{+++, s \S \S}$ \\
\hline Food intake (g/day) & $10 \cdot 6 \pm 0 \cdot 2$ & $8 \cdot 4 \pm 0 \cdot 4^{+++}$ & $8 \cdot 3 \pm 0 \cdot 4^{+++}$ \\
\hline
\end{tabular}

(GH and insulin), the data were log-transformed before analysis. Results are presented as the mean \pm S.E.M.

\section{Results}

Effects of a 4-week zinc deficiency

Confirming our previous report (Ninh et al. 1995), zinc deficiency decreased food intake $(-22 \%, P<0.001)$ and body weight gain $(-68 \%, P<0.001)$ compared with the CTRL animals (Table 1). Body weight gain during the last week was only $1 \pm 3 \mathrm{~g}$ in ZD rats compared with $7 \pm 2 \mathrm{~g}$ in CTRL animals (Table 2). By comparison with PF rats, who ate similar amounts of food, ZD rats had lower body weight gain $(-53 \%, P<0 \cdot 001)$, thymus weight $(-32 \%$, $P<0 \cdot 01)$, spleen weight $(-33 \%, P<0 \cdot 05)$ and kidney weight $(-18 \%, P<0 \cdot 01)$, thus indicating a specific deleterious effect of zinc deficiency on growth (Table 2).

Rat $\mathrm{GH}$ concentrations were decreased in both PF $(-68 \%, P<0 \cdot 05)$ and $\mathrm{ZD}(-76 \%, P<0.01)$ in comparison with CTRL rats (Table 3). Glycemia was similar in all groups and insulin concentrations were reduced by $50 \%$, albeit not significantly, in ZD rats by comparison with CTRL animals (Table 3 ).

By comparison with the PF animals, after 4 weeks zinc deficiency caused reductions in serum IGF-I concentrations $(-48 \%, P<0.01$; Fig. $1 \mathrm{~A})$ and in liver IGF-I mRNA levels $(-33 \%, P<0 \cdot 01$; Figs $1 \mathrm{~B}$ and 2$)$. The serum levels of IGFBP-3 were significantly lower in the $\mathrm{ZD}$ rats than in the CTRL animals $(-63 \%, P<0 \cdot 01)$, but not compared with PF rats $(-35 \%$, NS; Fig. 3A). Other IGF binding proteins were not significantly affected by any dietary manipulation (Fig. 4). Liver IGFBP-3 mRNA levels were similar among the three untreated dietary groups (Figs 2 and 3B).

\section{Effects of IGF-I administration during the last week}

Continuous infusion of IGF-I for the last week of the experimental period induced a marked stimulation of body weight gain in CTRL $(+12 \mathrm{~g}, \quad P<0.01$ vs untreated CTRL), and a less important, not significant effect in PF rats (+7 g, NS vs untreated PF) (Table 2). In contrast, ZD rats did not grow, despite IGF-I treatment. While the weight of most organs was increased in IGF-I-treated CTRL, only the spleen weight was increased by IGF-I infusion in $\mathrm{PF}$ and $\mathrm{ZD}$ rats. $(+50 \%, P<0 \cdot 05)$ (Table 2). IGF-I infusion did not significantly decrease serum insulin, except in $\mathrm{ZD}$ rats, but decreased endogenous rat GH levels in CTRL and ZD rats (Table 3). Glycemia (Table 3) and food intake (data not shown) were not affected by IGF-I infusion.

IGF-I administration doubled the serum IGF-I concentrations in the three groups of rats (CTRL: $+92 \%, P<0 \cdot 01$; PF: $+96 \%, P<0 \cdot 01$; ZD: $+93 \%, P<0 \cdot 001$, Fig. 1A). However, although the amount of infused IGF-I was identical for all rats, circulating IGF-I concentrations in IGF-I-treated ZD rats were only half those obtained in the two other treated groups, albeit normalized by comparison with untreated CTRL rats. A decrease in liver IGF-I mRNA levels was observed in all IGF-I-treated animals $(-40 \%$ in CTRL, $-38 \%$ in PF, $-45 \%$ in ZD, $P<0 \cdot 001$ ) (Figs $1 \mathrm{~B}$ and 2).

Serum IGFBP-3 and its liver mRNA levels were significantly increased (two-fold) in response to IGF-I

Table 2 Effect of a 4-week zinc deficiency and IGF-I infusion during the last experimental week on body and organ weight (g). Data are expressed as means \pm S.E.M. $(n=6 /$ group $)$

\begin{tabular}{|c|c|c|c|c|c|c|}
\hline & CTRL & CTRL + IGF-I & PF & PF+IGF-I & ZD & ZD+IGF-I \\
\hline $\begin{array}{l}\text { Body weight gain } \\
\text { (last week) }\end{array}$ & $6 \cdot 5 \pm 1 \cdot 7$ & $18 \cdot 3 \pm 1 \cdot 1^{* *}$ & $3 \cdot 3 \pm 1 \cdot 8$ & $10 \cdot 6 \pm 3 \cdot 5$ & $1 \cdot 2 \pm 3 \cdot 3^{+++}$ & $-0 \cdot 3 \pm 2 \cdot 3$ \\
\hline Final body weight & $128 \pm 2$ & $138 \pm 3^{*}$ & $110 \pm 4^{+++}$ & $114 \pm 4$ & $90 \pm 2^{+++, \S \S \S}$ & $92 \pm 3$ \\
\hline Liver & $4 \cdot 80 \pm 0 \cdot 19$ & $5 \cdot 62 \pm 0.22^{*}$ & $3 \cdot 84 \pm 0 \cdot 26^{+}$ & $3 \cdot 91 \pm 0 \cdot 40$ & $3 \cdot 13 \pm 0 \cdot 13^{+++}$ & $2 \cdot 93 \pm 0 \cdot 18$ \\
\hline Spleen & $0 \cdot 42 \pm 0.02$ & $0 \cdot 51 \pm 0 \cdot 04^{*}$ & $0.33 \pm 0.02^{+}$ & $0 \cdot 52 \pm 0.04^{* *}$ & $0 \cdot 22 \pm 0 \cdot 01^{+++, \S}$ & $0 \cdot 33 \pm 0 \cdot 15^{* *}$ \\
\hline Kidneys & $1 \cdot 13 \pm 0 \cdot 02$ & $1 \cdot 34 \pm 0 \cdot 02^{* * *}$ & $1 \cdot 12 \pm 0 \cdot 07$ & $1 \cdot 12 \pm 0 \cdot 04$ & $0.93 \pm 0.02^{++, \S \S}$ & $1 \cdot 03 \pm 0.02$ \\
\hline
\end{tabular}


Table 3 Effect of a 4-week zinc deficiency and IGF-I infusion during the last experimental week on circulating hormones and glucose. Data are expressed as geometric mean with the $95 \%$ confidence interval for $\mathrm{GH}$ and insulin and the mean \pm S.E.M. for glycemia ( $n=6 /$ group)

\begin{tabular}{|c|c|c|c|c|c|c|}
\hline & CTRL & CTRL + IGF-I & PF & PF+IGF-I & ZD & ZD+IGF-I \\
\hline $\mathrm{rGH}(\mathrm{ng} / \mathrm{ml})$ & $\begin{array}{l}20 \\
(12-38)\end{array}$ & $\begin{array}{l}4^{* *} \\
(1-12)\end{array}$ & $\begin{array}{l}6^{+} \\
(2-15)\end{array}$ & $\begin{array}{l}7 \\
(4-13)\end{array}$ & $\begin{array}{l}4^{++} \\
(1-13)\end{array}$ & $\begin{array}{l}1^{*} \\
(1-2)\end{array}$ \\
\hline Insulin (ng/ml) & $\begin{array}{l}0 \cdot 63 \\
(0 \cdot 35-1 \cdot 12)\end{array}$ & $\begin{array}{l}0 \cdot 69 \\
(0 \cdot 31-0 \cdot 55)\end{array}$ & $\begin{array}{l}0 \cdot 52 \\
(0 \cdot 21-1 \cdot 32)\end{array}$ & $\begin{array}{l}0 \cdot 29 \\
(0 \cdot 14-0 \cdot 60)\end{array}$ & $\begin{array}{l}0 \cdot 26 \\
(0 \cdot 15-0 \cdot 46)\end{array}$ & $\begin{array}{l}0 \cdot 16^{*} \\
(0 \cdot 13-0 \cdot 20)\end{array}$ \\
\hline Glucose (g/l) & $1 \cdot 03 \pm 0.03$ & $1.09 \pm 0.04$ & $0.95 \pm 0.04$ & $1.02 \pm 0.05$ & $1 \cdot 03 \pm 0.07$ & $0.94 \pm 0.06$ \\
\hline
\end{tabular}

${ }^{*} P<0 \cdot 05,{ }^{* *} P<0 \cdot 01$ vs the corresponding untreated group; ${ }^{+} P<0 \cdot 05,{ }^{++} P<0 \cdot 01$ vs CTRL.

infusion in the three dietary groups (for IGFBP-3: $+68 \%$ in CTRL, $P<0 \cdot 001 ;+127 \%$ in PF, $P<0 \cdot 001 ;+151 \%$ in ZD, $P<0 \cdot 01$; for IGFBP-3 mRNA: $+71 \%$ in CTRL, $P<0 \cdot 05 ;+94 \%$ in PF, $P<0 \cdot 01 ;+121 \%$ in $\mathrm{ZD}, P<0 \cdot 001)$ (Figs 2, 3 and 4). Serum IGFBP-3 in treated ZD rats was normalized by comparison with untreated CTRL rats (Fig. 3A). There was a good correlation between serum IGF-I and IGFBP-3 $(r=0 \cdot 85, P<0 \cdot 0001)$ in all groups.
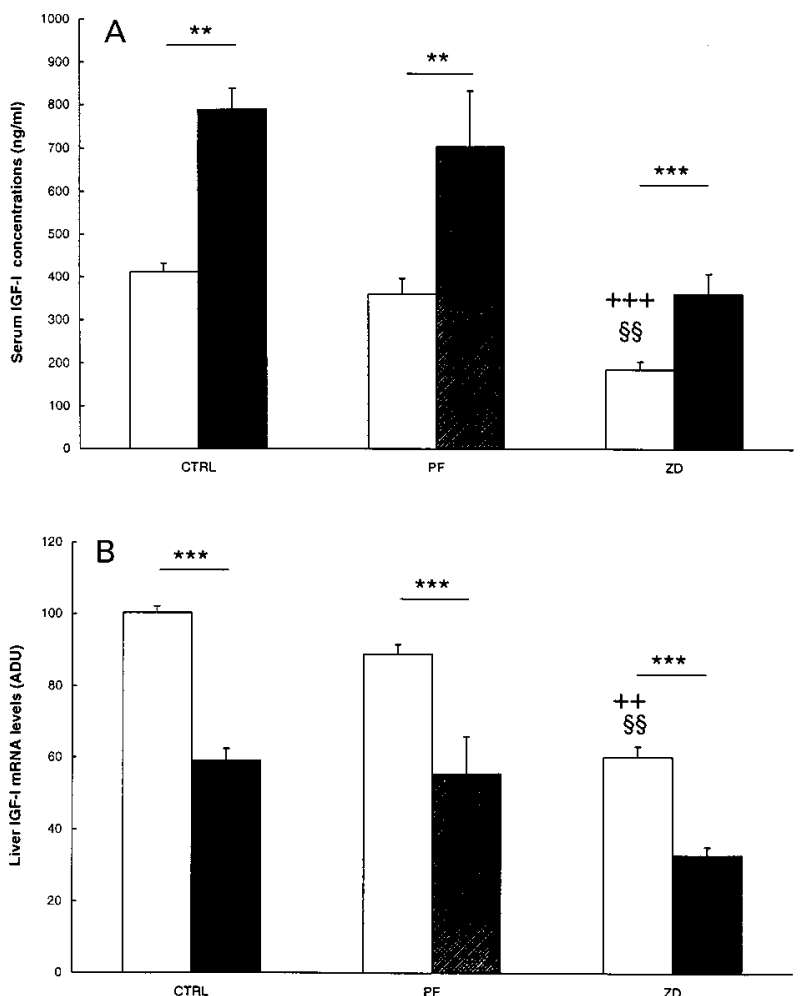

Figure 1 Serum IGF-I concentrations (A) and liver IGF-I mRNA levels (B) in CTRL, PF and ZD rats, treated (solid bars) or not (open bars) with rhIGF-I $(120 \mu \mathrm{g} /$ day $)$. Data are mean \pm S.E.M. of six rats per group. ${ }^{* *} P<0 \cdot 01$ and ${ }^{* * *} P<0.001$ between the indicated groups; ${ }^{++} P<0.01$ and ${ }^{+++} P<0.001$ vs CTRL; ${ }^{\$} P<0.01$ vs $P F$. ADU =arbitrary scanning densitometric units.

\section{Discussion}

Our results show that the growth retardation caused by dietary zinc deficiency cannot be reversed by IGF-I infusion, despite normalization of circulating IGF-I. This observation strongly suggests that the decrease of serum IGF-I is not the only mechanism responsible for the growth retardation caused by zinc deprivation. When growth retardation results from $\mathrm{GH}$ deficiency, as in hypophysectomized rats, IGF-I infusion restores growth, even without normalization of circulating IGF-I (Schoenle et al. 1982). Thus, in normally fed rats, IGF-I infusion increases body weight gain and the weight of several organs and therefore mimics the growth-promoting action of $\mathrm{GH}$, in contrast to what is observed in $\mathrm{ZD}$ rats. Furthermore our results show that IGF-I may still exert a detectable growth-promoting effect in PF rats which are, however, partially calorie and protein restricted. This

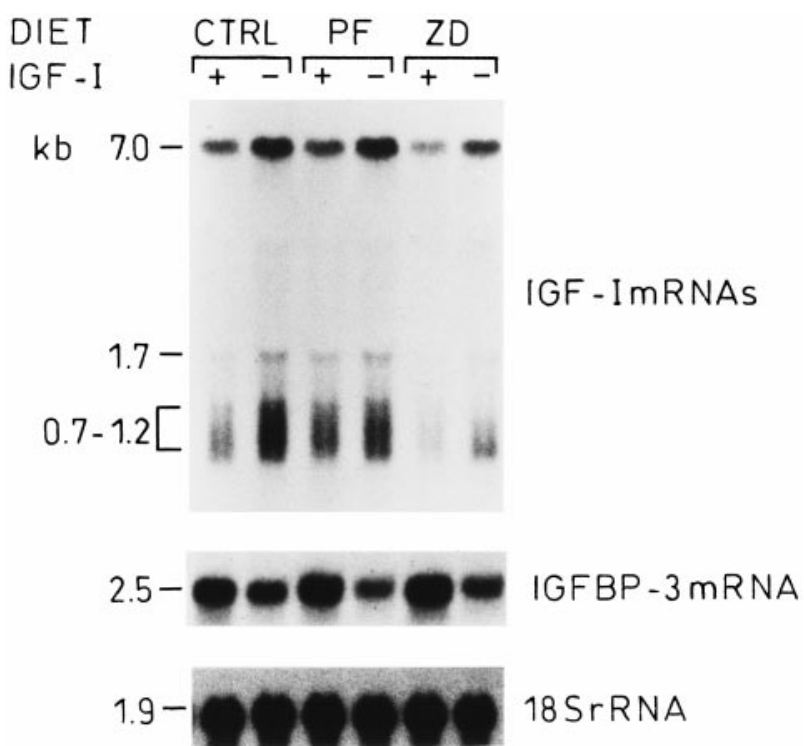

Figure 2 Northern blots of liver IGF-I mRNA, IGFBP-3 mRNA and $18 \mathrm{~S}$ rRNA in CTRL, PF and ZD rats, treated or not with rhIGF-I $(120 \mu \mathrm{g} /$ day). Representative data are shown for one animal per group. 

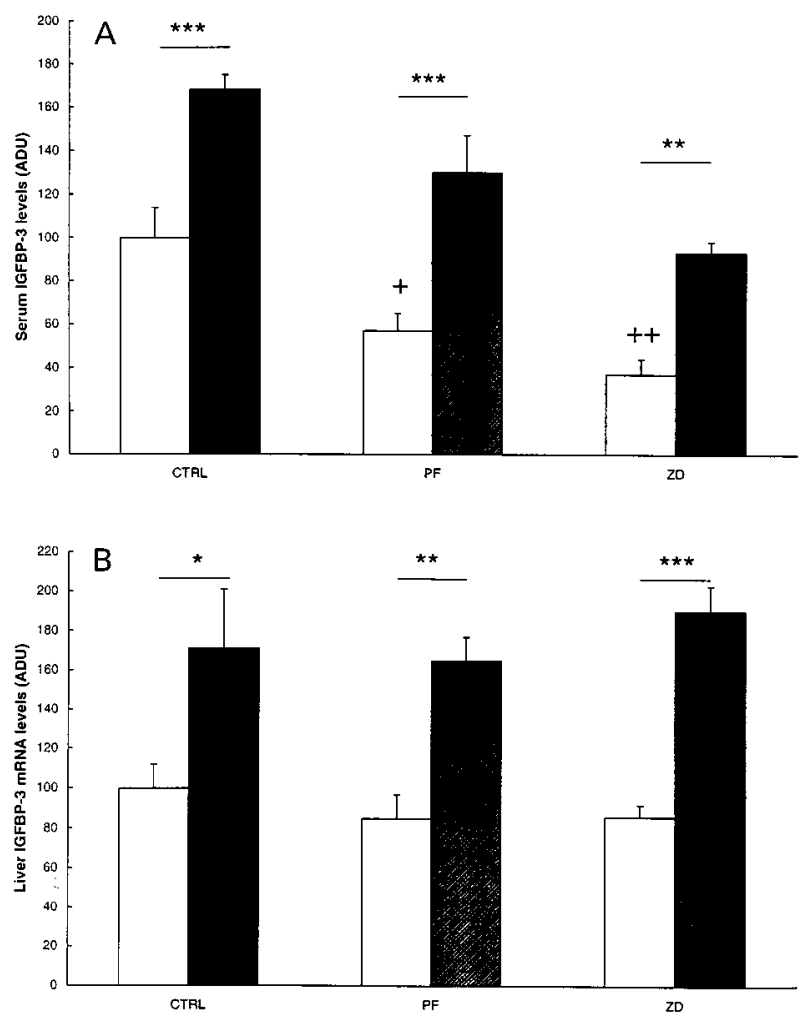

Figure 3 Serum IGFBP-3 levels (A) and liver IGFBP-3 mRNA levels (B) in CTRL, PF and ZD rats, treated (solid bars) or not (open bars) with rhlGF-I $(120 \mu \mathrm{g} /$ day). Data are means \pm S.E.M. of six rats per group. ${ }^{*} P<0 \cdot 05,{ }^{* *} P<0 \cdot 01$ and ${ }^{* * *} P<0 \cdot 001$ between the indicated groups; ${ }^{+} P<0.05$ and ${ }^{++} P<0.01$ vs $C T R L$. ADU $=$ arbitrary scanning densitometric units.

indicates that zinc per se is necessary for the full expression of the anabolic action of IGF-I. Because the anabolic response to IGF-I is nevertheless slightly reduced in PF animals by comparison with CTRL, we must recognize that generalized nutritional deprivation may impair the activity of this growth factor. The anabolic action of IGF-I in vivo is therefore dependent on the availability not only of protein (Thissen et al. 1991a) and calories (Philipps et al. 1988), but also of zinc. Since zinc plays a role in many

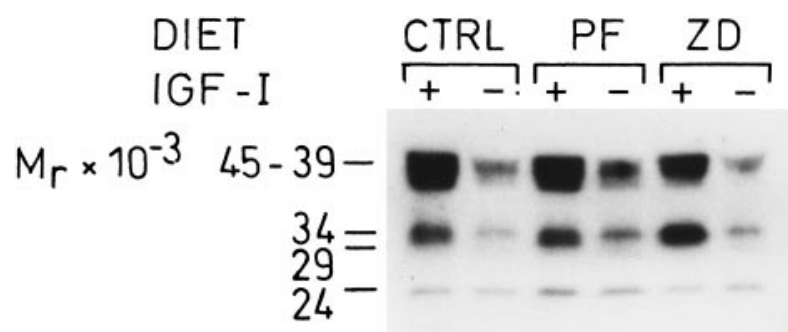

Figure 4 Representative ligand blot of serum IGFBPs in CTRL, PF and ZD rats, treated or not with rhIGF-I (120 $\mu$ g/day). Data are shown for one animal per group. aspects of cell function, there are probably many sites in the IGF-I action that zinc could potentially mediate. The fact that zinc is necessary for fibroblasts to enter into $\mathrm{S}$ phase suggests that the stimulation of DNA synthesis by IGF-I may be inhibited in the presence of zinc deficiency (Chesters et al. 1989). Such an observation supports the conclusion that zinc is required for the mitogenic action of IGF-I. The growth-promoting effect of IGF-I on spleen is, however, not impaired by the reduced availability of zinc and calories.

Despite the infusion of an identical amount of IGF-I (and even a higher dose per $\mathrm{g}$ of body weight), the IGF-I concentrations reached in ZD rats remained lower than those observed in IGF-I treated PF and CTRL rats. This difference in IGF-I concentrations observed may result from accelerated clearance and/or degradation, as described in protein-restricted animals (Thissen et al. 1992). This hypothesis is also strengthened by the observed decline in ZD rats of circulating IGFBP-3, the main carrier of IGF-I in the blood. Therefore, we cannot formally exclude that the absence of growth response of $\mathrm{ZD}$ rats treated with IGF-I might be related in part to insufficient increase of IGF-I concentrations. Nevertheless, comparable serum levels were sufficient to promote growth in untreated CTRL rats.

Several hypotheses may be proposed to explain the failure of exogenous IGF-I to stimulate growth in ZD animals.

First, the anabolic action of IGF-I might be limited by the action of IGFBPs. Although the circulating levels of most major IGFBPs are decreased in response to zinc deprivation (Clegg et al. 1995, Ninh et al. 1997), it is possible that this decline in blood reflects an increase of IGFBPs (mainly IGFBP-3) at the cell surface where they could limit the access of IGF-I to the type 1 IGF receptor (Conover 1991). The marked decrease of serum IGFBP-3 levels in response to zinc deprivation together with the minimal changes in liver IGFBP-3 mRNA levels supports this possibility. Alternatively, the decline of IGFBP-3 might result from proteolytic degradation, but this hypothesis is not supported by the recent data reported by Clegg et al. (1995). Furthermore, zinc supplementation in vitro has been reported to enhance binding of IGF-I to its receptor and decrease the binding to its IGFBPs (Mateski \& McCusker 1995). It is therefore possible that, in the absence of zinc, IGF-I is preferentially bound to cell surface IGFBPs, preventing its interaction with the type 1 IGF receptor.

Secondly, although IGF-I and IGFBP-3 levels are normalized by exogenous IGF-I, the acid-labile subunit (ALS), the third component of the ternary complex, is still probably reduced. Both nutritional restriction (Dai \& Baxter 1994, Takenaka et al. 1996) and GH deficiency (Labarta et al. 1997), which are present in ZD rats, have been reported to decrease ALS production. Furthermore, exogenous IGF-I, by decreasing GH secretion as suggested 
by reduced GH plasma levels, might even worsen the decrease of circulating ALS levels (Kupfer et al. 1993). Given its crucial role in the formation of the ternary IGF complex, low ALS levels may potentially impair the formation of this complex. As IGF-I bound to the ternary complex seems to represent the most potent anabolic form of circulating IGF-I (Kupfer et al. 1993), reduced formation of this complex may contribute to decreased IGF-I bioactivity in $\mathrm{ZD}$ rats.

Thirdly, the resistance to IGF-I action in ZD rats may also be mediated by reduced numbers of type 1 IGF receptor. This hypothesis is supported by a recent report showing that decreased DNA synthesis in zinc-depleted $3 \mathrm{~T} 3$ fibroblasts is associated with decreased IGF-I binding (McDonald \& O'Dell 1995). If such a mechanism is operational in vivo, it might contribute to the reduced action of IGF-I in ZD rats.

Finally, the possibility remains that zinc impairs cell proliferation and growth by a mechanism independent of IGF-I. Indeed, zinc deprivation might impair cell proliferation at a step distal to IGF-I action, such as reduced thymidine kinase activity or DNA polymerase (Chesters et al. 1990). If it is the case, zinc-deficient animals should be resistant to the action of any growth factor.

In conclusion, the decline of circulating IGF-I in zinc-deprived rats is not the only cause of their growth retardation. This seems also, if not predominantly, related to a resistance to the anabolic action of this growth factor.

\section{Acknowledgements}

This work was supported by scholarship from the University of Louvain to $\mathrm{NXN}$ and by grants from the Belgian National Fund for Scientific Research (\#3-4559.93), from the Fund for Scientific Development, University of Louvain (Belgium) and from the Danone Institute (Brussels, Belgium). J P T is a Research Associate of the National Fund for Scientific Research (Belgium).

\section{References}

Bolze MS, Reeves RD, Lindbeck FE \& Elders MJ 1987 Influence of zinc growth, somatomedin, and glycosaminoglycan metabolism in rats. American Journal of Physiology 252 E21-E26.

Chesters JK, Petrie L \& Vint H 1989 Specificity timing of the $\mathrm{Zn}^{2+}$ requirement for DNA synthesis by $3 \mathrm{~T} 3$ cells. Experimental Cell Research 184 499-508.

Chesters JK, Petrie L \& Travis AJ 1990 A requirement for $\mathrm{Zn}^{2+}$ for the induction of thymidine kinase but not ornithine decarboxylase in 3 T3 cells stimulated from quiescence. Biochemical Journal 272 525-527.

Chirgwin JM, Przybla AE, MacDonald RJ \& Rutter WJ 1977 Isolation of biologically active ribonucleic acid from sources enriched in ribonucleases. Biochemistry 18 5294-5299.

Clegg MS, Keen CL \& Donovan SM 1995 Zinc deficiency-induced anorexia influences the distribution of serum insulin-like growth factor-binding proteins in the rat. Metabolism 44 1495-1501.
Clemmons DR, Thissen JP, Maes M, Ketelslegers JM \& Underwood LE 1989 Insulin-like growth factor-I (IGF-I) infusion into hypophysectomized or protein-deprived rats induces specific IGF-binding proteins in serum. Endocrinology 125 2967-2972.

Conover CA 1991 A unique receptor-independent mechanism by which insulin-like growth factor-I regulates availability of insulin-like growth factor binding proteins in normal and transformed fibroblasts. Journal of Clinical Investigation 88 1354-1361.

Cossack ZT 1984 Somatomedin-C in zinc deficiency. Experientia 40 498-500.

Dai J \& Baxter RC 1994 Regulation in vivo of the acid-labile subunit of the rat serum insulin-like growth factor-binding protein complex. Endocrinology 135 2335-2341.

Davenport ML, Svoboda ME, Koerber KL, Van Wijk JJ, Clemmens DR \& Underwood LE 1988 Serum concentrations of insulin-like growth factor-II are not changed by short term fasting and refeeding. Journal of Clinical Endocrinology and Metabolism 67 1231-1236.

Dorup I, Flyvberg A, Everts ME \& Clausen T 1991 Role of insulin-like growth factor-I and growth hormone in growth inhibition induced by magnesium and zinc deficiencies. British Journal of Nutrition 66 505-521.

Gronowski AM \& Rotwein P 1995 Rapid changes in gene expression after in vivo growth hormone treatment. Endocrinology 136 $4741-4748$

Kupfer SR, Underwood LE, Baxter RC \& Clemmons DR 1993 Enhancement of the anabolic effects of growth hormone and insulin-like growth factor-I by use of both agents simultaneously. Journal of Clinical Investigation 91 391-396.

Labarta JI, Gargosky SE, Simpson DM, Lee PDK, Argente J, Guevara-Aguirre J \& Rosenfeld RG 1997 Immunoblot studies of the acid-labile subunit (ALS) in biological fluids, normal human serum and in children with GH deficiency and GH receptor deficiency before and after long-term therapy with GH or IGF-I respectively. Clinical Endocrinology 47 657-666.

McDonald RS \& O'Dell BL 1995 Inhibition of cell division in 3T3 cells by zinc depletion is associated with decreased IGF-I receptors. Abstract 5031. Experimental Biology '95 Meeting, Atlanta, GA, USA.

Maes M, Ketelslegers JM \& Underwood LE 1983 Low plasma somatomedin-C in streptozotocin-induced diabetes mellitus: correlation with changes in somatogenic and lactogenic liver binding sites. Diabetes 32 1060-1069.

Maiter D, Fliesen T, Underwood LE, Maes M, Gerard G, Davenport ML \& Ketelslegers JM 1989 Dietary protein restriction decreases insulin-like growth factor I independent of insulin and liver growth hormone binding. Endocrinology 124 2604-2611.

Mateski RL \& McCusker RH 1995 Ligand affinity of insulin-like growth factor binding proteins (IGFBPs) on cell surfaces in the presence of lanthanum and zinc. Abstract. 77th Annual Meeting of the Endocrine Society, 14-17 June 1995, Washington DC, USA.

Ninh NX, Thissen J-P, Maiter D, Adam E, Mulumba N \& Ketelslegers J-M 1995 Reduced liver insulin-like growth factor-I gene expression in young zinc-deprived rats is associated with a decrease in liver growth hormone $(\mathrm{GH})$ receptors and serum GH-binding protein. Journal of Endocrinology 144 449-456.

Ninh NX, Maiter D, Lause P, Chrzanowska B, Underwood LE, Ketelslegers J-M \& Thissen J-P 1997 Continuous administration of growth hormone $(\mathrm{GH})$ does not prevent the decrease of IGF-I gene expression in zinc-deprived rats despite normalization of liver $\mathrm{GH}$ binding. Growth Regulation 7 1-8.

Oner G, Bhaumick B \& Bala RM 1984 Effect of zinc deficiency on serum somatomedin levels and skeletal growth in young rats. Endocrinology 114 1860-1863.

Philipps AF, Persson B, Hall K, Lake M, Skottner A, Sanengen T \& Sara VR 1988 The effects of biosynthetic insulin-like growth factor-I supplementation on somatic growth, maturation, and erythropoiesis on the neonatal rat. Pediatric Research 23 298-305. 
Schoenle E, Zapf J, Humbel RE \& Froesch ER 1982 Insulin-like growth factor-I stimulates growth in hypophysectomized rats. Nature $296252-253$.

Takenaka A, Mori M, Yamada S, Ohgane J, Takahashi SI \& Noguchi T 1996 Nutritional regulation of gene expression of insulin-like growth factor-binding proteins and the acid-labile subunit in various tissues of rats. Journal of Endocrinology 150 33-41.

Thissen JP, Triest S, Moats-Staats BM, Underwood LE, Mauerhoff T, Maiter D \& Ketelslegers JM 1991a Evidence that pretranslational and translational defects decrease serum IGF-I concentrations during dietary protein restriction. Endocrinology 129 429-435.

Thissen JP, Underwood LE, Maiter D, Maes M, Clemmons DR \& Ketelslegers JM $1991 b$ Failure of IGF-I infusion to promote growth in protein-restricted rats despite normalization of serum IGF-I concentrations. Endocrinology 128 885-890.

Thissen JP, Davenport ML, Pucilowka J, Miles MV \& Underwood LE 1992 Increased serum clearance and degradation of $\left[{ }^{125} \mathrm{I}\right]$ labelled IGF-I in protein-restricted rats. American Journal of Physiology 262 E406-E411.

Thissen JP, Ketelslegers JM \& Underwood LE 1994 Nutritional regulation of insulin-like growth factor-I. Endocrine Reviews $\mathbf{1 5 0}$ 80-101.

Received 26 February 1998

Revised manuscript received 28 May 1998

Accepted 15 June 1998 